\title{
The Impact of Using Edmodo on Saudi University EFL Students' Motivation and Teacher-Student
}

\section{Communication}

\author{
Shatha Turki Alshawi ${ }^{1, *} \&$ Faisal Abdullah Alhomoud ${ }^{2}$ \\ ${ }^{1}$ Faculty of Education, Princess Nourah bint Abdulrahman University, Riyadh, Saudi Arabia \\ ${ }^{2}$ Faculty of Languages and Translation, Al-Imam Muhammad Ibn Saud Islamic University, \\ Riyadh, Saudi Arabia \\ *Correspondence: Faculty of Education, Princess Nourah bint Abdulrahman University, \\ Riyadh, Saudi Arabia. E-mail: shatha-turki@hotmail.com
}

Received: November 23, 2016 Accepted: December 7, 2016 Published: December 22, 2016

doi:10.5296/ije.v8i4.10501ＵRL: http://dx.doi.org/10.5296/ije.v8i4.10501

\begin{abstract}
Edmodo is a free educational networking site that provides a secure online learning platform for both teachers and students. The current research explored the impact that Edmodo has on students' engagement in EFL learning as well as their motivation towards learning that language. The research was conducted on 255 female students at Princess Nourah bint Abdulrahman University, Saudi Arabia. The participants were involved in daily interactions with their peers as well as their teachers via Edmodo features and applications, e.g. posing questions, submitting assignments, discussions, and teachers' feedback. The present paper posed two research questions: 1. What is the impact of the educational networking site Edmodo on students' motivation? 2. What is the impact of the educational networking site Edmodo on teacher-student's communication? In order to explore the possible answers, a 40-item questionnaire was administered to the participants. The first 21 items were designated to explore students' motivation for learning EFL through Edmodo, while the remaining items explored students' beliefs about the impact that Edmodo has on their communication with their teachers. All items were answered using a 4-point Likert scale ranging from strongly agree to strongly disagree. The results indicated statistically significant motivation towards language learning due to the use of Edmodo. It also showed that the teacher-student's interaction is highly significant via Edmodo. Furthermore, students mainly preferred quizzes and assignments on Edmodo when they are designed effectively. The results of this study may encourage teachers to integrate educational networks to create effective online learning classes for their students.
\end{abstract}

Keywords: Communication, Edmodo, EFL, Motivation, Social Networks 


\section{Introduction}

\subsection{Introduction}

It is increasingly evident that social networking sites play an important role in everyday life. Whether big or small, people now report incidents every split of a second, as they occur. People are also relying more and more on mobile devices as their primary communication tool and increasingly using these devices to access social networking sites. In education, school administrators should effectively employ this technology. Teachers who seek for ways to enhance teaching and learning, Edmodo can be a clever and easy way to ensure the success. Edmodo gives teachers the opportunity to create a sense of community in which they can build relationships with learners and communicate different kinds of information.

Edmodo describes itself as a free educational website that is structured as a social network, designed for teachers and students with intuitive features and unlimited storage. It gives teachers the opportunity to communicate with their students via private and public messages, send alerts and announcements, award badges, post assignments, discussions, polls and quizzes, assign grades, share resources, lay out course calendar and create small groups for projects. Also, students can connect easily to their teachers, send questions, upload files and links to their backpack (e-library), submit assignments, take quizzes, collaborate, share, discuss, and participate in polls. Edmodo use depends heavily on the teachers and on the features they utilize in their teaching process.

What makes this social network distinct is that it has features that are particularly designed for educational purposes. The availability of such features can give students opportunities to practice new skills and deepen their understanding of new information. They can help teachers create engaging learning activities, challenge students' understanding, provide a sense of flexibility in time and place of learning and give feedback on students' performance.

\subsection{Statement of the Problem}

Learning is seen as essentially a social process requiring communication between teachers and students. To stress the importance of communication in learning and teaching, Hurt, Scott, and McCroskey (1978) remarked, "Communication is the crucial link between a knowledgeable teacher and a learning student" (as cited in Beebe \& Mottet, 2009: 349). After school hours, students struggle in finding ways to contact their teachers without violating their privacy. Emails are the most common way, but still students are trying to find faster and easier ways to communicate and interact at the same time. They need to feel that they are a part of a community where their needs are respected and their ideals are understood. On the other hand, teachers need to take into account what students want or need. Student involvement contributes positively to the learning process. If they are involved, they devote time and energy to learn with interest. This interest leads to a unique school experience.

Furthermore, as a main component in the education system, teachers must be taken into consideration. They never have enough time. They have syllabus to cover, skills to improve, quizzes to do, papers to correct, grades to record and seminars to attend. They often feel overwhelmed by the endless demands of teaching in and outside the classroom. Thus, they 
need a way to save their time and effort without negatively affecting the learning process. Edmodo might be one of the keys that change the way students learn and the way teachers teach. It can facilitate communication and create a dynamic online community. Edmodo also opens the door to broader communications between students and other educational institutions. This feature gives students the opportunity to exchange ideas, thoughts and inquiries with other students from different backgrounds.

Motivation is the key to success in learning (Dörnyei, 1998). Therefore, smart teachers seek for modern approaches to increase their students' motivation. Edmodo seems to have a potential to change the way students learn, stimulate their motivation and push them forward. Edmodo is commonly referred to as a "Facebook for school". It is designed to get students eager to learn and to keep them in a familiarly attractive environment. In this site, students can easily find their curriculum, related subjects, assignments, quizzes, grades and even groups to chat with, all in one organized place. The availability of such features makes learning easier and more interesting. Students who find it too stressful to speak orally can interact with other students and teachers via Edmodo. Through its online discussion, Edmodo's communities stimulate further inquiry among students and this might enrich the learning process with more information and experiences. Teachers also can figure out what students want and need to add as lessons or design as instructions. One of Edmodo's excellent features is that it facilitates student-centric decisions via polling. This feature provides students with confidence and comfort, and teachers with insight into students' learning process. Besides, Edmodo offers teachers a way to reward students for their participation and work completion with badges. This feature can create a sense of rivalry among students and encourage them to get higher grades, i.e. motivate them.

\subsection{Research Questions}

1. What is the impact of the educational networking site Edmodo on EFL students' motivation?

2. What is the impact of the educational networking site Edmodo on teacher-student communication?

\subsection{Significance of the Study}

The current study has theoretical and pedagogical significance, which derives from the following reasons:

1. To the best of my knowledge, few if any studies have investigated the impact of Edmodo on Saudi University EFL students' motivation and teacher-student communication.

2. The study may raise EFL teachers' awareness to the importance of incorporating social networks in their classrooms and be up to date with the latest technological advances in education.

3. The findings of the study may contribute enormously to solve many educational problems, hence make the teaching and learning process easier for both teachers 
and students.

4. The study may also help enlighten the decision makers in the Ministry of Education to the significance of creating an interactive community where everybody, school administrators, teachers, students and even parents, can participate to produce a successful and unique educational process, thus legislate its use in the educational institutions.

5. The study may provide insights on the status of Edmodo as an educational social networking site and its suitability to the Saudi environment.

6. It is hoped that the findings of the study will contribute to the previous literature in the field of education, particularly foreign language learning.

\subsection{Limitations of the Study}

All studies, despite of how well it is built and conducted, have limitations (Simon \& Goes, 2013). Due to time and access constraints, the present study is limited to female Saudi EFL students from Princess Noura bint Abdulrahman University. It is also limited to those students who had an experience with Edmodo in their language learning process in 2013-2014. By only obtaining data from the study population i.e. Princess Noura University EFL students, the study might be limited in scope.

\section{Literature Review}

\subsection{Social Networks in Education}

Social networks generally feature unique online services integrated through the Internet meant for virtual social lives developed by people with the aim of enabling free interaction among people (Tiryakioglu \& Erzurum, 2011). Social networks that in other words represent social media seem to influence almost every little aspect of human life, and the field of education is not an exception in this case. Khedo et al. (2012) posit that, "Information and communication technology is known to help expand access to education, strengthen the relevance of education to the increasingly digital workplace, and raise educational quality" ( $p$. 907).

A continuum of studies has emerged across the research industry with an aim of elaborating on how social networking sites (SNS) have created a unique impact in the formal education setting. Hershkovitz and Baruch (2010) add, "Internet integration in higher education has stimulated high expectations, especially regarding accessibility, interactivity and opportunities for improved instruction" (p. 14). However, as noted by Zaidieh (2012), social networks come with unique challenges integrated into the educational system and some of such challenges include privacy concerns among educators and learners, miscommunication and time consuming.

In the context of the impact of social networking sites on education, studies have identified great contributions of social media in educational systems. Khedo et al. (2012) examined the 
use of online social networking (OSN) as a tool to enhance learning in the Mauritian education system. This study investigated the use of OSNs by secondary school students, aged 12-18, in a targeted population of approximately 4000 learners. When questioned whether they have undertaken educational activities via OSN, 58.3\% of the participants agreed that they used OSNs for educational intentions (Khedo et al., 2012). From this study, improvements in communication as a learning aspect emerged; as $80.5 \%$ of learners revealed that they used OSN as communication tools through chatting and messaging. They also stated that OSN provide flexible learning as $51.9 \%$ agreed that they frequently accessed OSN sites daily.

Following the same study, it was evident that social networks in Mauritius schools played a significant role in school learning activities as some common educational activities that students engaged in involved discussing class activities (48.8\%), looking for help from peers $(69.3 \%)$, discussing exam papers $(32.7 \%)$, as well as undertaking group work online $(39.0 \%)$. In an in-depth examination of the impact of OSN, Khedo et al. (2012) questioned learners whether the features found on these sites are useful in their educational activities. Accordingly, $80.5 \%$ of students responded that they used chatting and messaging to connect with friends, $41.7 \%$ agreed that they used their accounts to join or form discussion groups, and $25.3 \%$ in asking academic questions to their classmates. Finally, $16.2 \%$ of learners used their profiles in sharing files in the form of photos and videos containing educational contents.

As web 2.0 continues to expand across learning institutions, its uptake, though in low rates, seems to influence learning through communication and information sharing (Barbour \& Plough, 2009). In a study to examine the benefits and drawbacks of social media in education, Gamoran (2011) notices that approximately $90 \%$ of college students visit a social networking site daily. He also reveals that social media tools motivate students to communicate with each other and exchange their creative ideas. This assertion shows that learners are capable of sharing and developing practical reasoning while using social networks.

\subsection{Famous Social Networks}

Popular social networking sites including Facebook, LinkedIn, MySpace, and even Twitter seem to have influenced learners in educational institutions. Brady, Holcomb, and Smith (2010) investigated in their study learners' awareness of the advantages found in employing social networking technologies in education. From fifty graduate students who participated in an online survey, the study found that $14 \%$ of students had MySpace accounts and $30 \%$ had Facebook accounts. When questioned on the importance of social networks in education, approximately $30 \%$ of learners indicated that they had used SNS for educational purposes. Another study conducted by Tiryakioglu and Erzurum (2011) examined instructors' perceptions of Facebook as a communication tool. Sixty-seven instructors working in the faculty of communication sciences at a Turkish university contributed to this study. It was found that $75 \%$ of the instructors possessed active Facebook accounts, 56\% indicated that they use Facebook daily, and approximately $66 \%$ think positively about Facebook. However, these social networking sites, especially Facebook, have been frequently criticized for 
privacy concerns (del Val et al., 2010; Young \& Quan-Haase, 2009). Thus, other social networks intended for educational purposes are recommended to be used (del Val et al., 2010).

Among the rapidly growing social networks associated with distance learning or e-learning in the modern world educational system is the Edmodo social learning platform that emerged as an educational social network (Thongmak, 2013). Kongchan (2012) described Edmodo as a free social learning website which provides a safe and easy way for teachers and their students to connect and collaborate, share content, and access class work in an online environment. Since its advent into the educational system in 2008, Edmodo is gradually picking and users are expressing their perceptions through different researches (Fardoun et al., 2012). Edmodo has proved influential in the educational paradigm thus making it receive substantial familiarity with instructors using it as a communication and instructional delivery tool for learners. With its ability to give a safe and secure social network designed specifically to support instructors and learners, Edmodo seems more effective than other social networks are as it possesses education-specific applications (Weber, 2012).

\subsection{Teachers' Perspectives on Edmodo}

Teachers are important partners in any educational paradigm, and the success of students as well as the integration of Edmodo relies on these important factors. Edmodo has features that have attracted several instructors and made them have greater teaching experiences compared to other traditional social networking sites across the world (Greenhow \& Robelia, 2009). Teachers normally need time to interact with learners and understand them better. Flexibility, as an aspect in Edmodo, is quite significant in teachers scheduling and planning behaviour as teachers enjoy the flexibility in assessing their students despite their geographical position. In an examination of how Edmodo worked in schools, especially in relation to teacher's engagement, Kirschner and Karpinski (2010) noticed that in some schools, teachers organised collaborative teams that contained formative student information to help them in planning instruction and assessment strategies based on the curriculum units. On a broader perspective, Conole (2010) asserts that teachers could engage with each other on academic issues and help one another in discussing important matters.

Unlike other educational social networks, Edmodo' ease of use even for non-digital-native teachers puts it at the top of the chart. Kongchan (2012) investigated how a non-digital-native teacher can make use of Edmodo as an online classroom community for her students, and to set a workshop on Edmodo for other teachers. The teacher-researcher employed the programme effectively without the help of an IT expert. She also revealed in her diary that she likes using Edmodo due to its simple and user-friendly functions. Furthermore, the data gathered from the 17 teachers who attended the Edmodo workshop showed a high level of acceptance and response owing to its easiness and efficiency (Kongchan, 2012).

Through Edmodo, teachers join communities to share information, connect with other members, find resources, exchange ideas, and ask for feedback or help. Teachers use posts to ask for teachers who want to Skype with their class, join their school on a project, or pair with their class for pen pals. For instance, a science teacher in the Science community on 
Edmodo asked for suggestions on articles and resources for a literacy-based lesson in Earth science, and in one day the teacher received several responses and links from other teachers (Winant, 2014). Hewes (2010), a blogger and full-time teacher, describes Edmodo as her most favourite web 2.0 tool because it has become her virtual learning space. She refuses to refer to it as a classroom because it connotes four walls and isolated teaching and learning, which in her opinion, is the contrary. Picardo (2010), a blogger and assistant principal at a prominent high school in England, expressed his desire to find a means for the students to communicate with their teachers and with each other in an attractive and natural way that suits their technological expectations and skills. He highlighted crucial features on Edmodo that lead to its adoption by his school such as convenience, communication, democratisation and personalisation of the learning experience.

\subsection{Edmodo and Students' Motivation}

Educational attainment using Edmodo has been successful following a great number of positive responses among students and instructors. Scholars describe social-networking sites as attractive means for meaningful communication and effective collaboration (Zaidieh, 2012). The sense of being convenient and flexible makes Edmodo, just like other SNS, attractive and motivating for learners by virtue of its accessibility (Selwyn, 2009). Sanders (2012) indicated that Edmodo encourages both student engagement and responsible learning. It allows electronic collaboration through its platform where students' engagement and enjoyment in learning grows, thus making learners motivated as they engage in higher order thinking spurred by online communities.

A recent study conducted by Wolfer (2012) raised a number of issues related to motivation. The study collected data on learners' perception regarding the use of Edmodo after practically using the website for approximately a month. On a scale of 1-4, when questioned whether they enjoyed using it in learning, $42.1 \%$ of students provided a rating of 3 (deemed as good), while the majority of them accounting to $52.6 \%$ gave a rating of 4 (deemed as excellent). In a different study conducted by Fardoun et al. (2012), examining the impact of online social networks in secondary schools, the researcher noted that $95 \%$ have participated in Edmodo, $70 \%$ actively and constantly and $50 \%$ of students have spent their non-lecture hours on the website. Most importantly, $68.75 \%$ of students claimed that it was interesting to use Edmodo in education.

\subsection{Edmodo and Teacher-Student's Communication}

Online social networks as highlighted by different researchers are the most effective and powerful communication tools that connect million users across the globe (Baruah, 2012; Boyd \& Ellison, 2007). Zaidieh (2012) suggests that some informal learning through informal communication enhance students' collaboration and peer feedback regardless of time and place. Edmodo possesses unique communication features including blogging, texting, and file sharing features incorporated in the Edmodo platform, thus allowing instructors and learners to communicate effectively. It also involves creating online communities where both teachers and learners engage in classroom interactions online. 
In the context of improving communication between instructors and students, a study conducted by Thongmak (2013) reinforces this argument through online surveys conducted on students' perception of Edmodo. The participants were 182 undertaking a course in Management Information System. From the study, the researcher noticed that the majority of the learners argued that Edmodo is a good social networking system as it, according to 140 respondents, enables teachers to communicate directly with learners while giving instructions or assignments. Of the 182 respondents, over 145 of them agreed that this educative social network possesses a system that enables giving information, assigning homework, grading, and even updating news, an aspect that reveals improved communication between teachers and students. It also allows uploading or submitting files to instructors, which enables constant assessment of learners. Moreover, learners indicated that instructors are capable of easily checking finished assignments with more privacy compared to other social networks (Thongmak, 2013).

Nonetheless, very few researches if any solely investigate the influences of using Edmodo on university students' motivation for and engagement in English learning. Therefore, objectives of this paper are to enrich previous researches by focusing on these two major aspects of English learning; to examine the impact of Edmodo on students' motivation and teacher-students' communication; to find out about students' perceptions of its use in their learning process; and to aid teachers in motivating students to join these educational social networks.

\section{Methodology}

\subsection{Population and Sample of the Study}

The population of the study was Saudi EFL students at Princess Nourah bint Abdulrahman University in Riyadh. Their ages ranged around 18 to 23 years old. They were EFL students who were using the educational networking site Edmodo in their language learning process. The sample of the study was 255 EFL Saudi students selected randomly from Princess Nourah bint Abdulrahman University in Riyadh. Most of them log into Edmodo daily, and are members in more than one group there.

\subsection{Instruments of the Study}

The instrument used to find answers to the research questions was a structured questionnaire with close-ended questions to the students. The questionnaire examined the impact of the educational networking site Edmodo on two different variables: EFL students' motivation and teacher-student's communication in Princess Nourah bint Abdulrahman University. The questionnaire included 40 items; the first 21 items covered certain indicators of students' motivation in language learning through Edmodo: (1) internal factors such as, engaged learning activity, curiosity and challenge, interface design and ease of use, and (2) external/environmental factors such as, convenience, flexibility in time and place of learning, recognition and usefulness. The remaining 19 items designed to cover main aspects of teacher-student's communication in language learning situations via Edmodo: (1) verbal and 
non-verbal communication, and (2) confidentiality and effectiveness of communication.

\subsection{Instrument's Reliability and Validity}

A test of reliability on this survey instrument was conducted through SPSS on the data obtained from the pilot survey. Cronbach's alpha reliability coefficient typically ranges between 0 and 1; the closer it is to 1.0, the greater the internal consistency of the items in the scale (Cronbach, 1951). The reliability coefficients of the scales in this survey instrument ranged from 0.81 to 0.91 , which show a high range of values for Cronbach's alpha coefficient.

To ensure the content validity, the supervisor who is a Ph.D. holder in the field of applied linguistics and five experts in linguistics, psychology and English teaching Methods reviewed the instrument and provided feedback throughout the initial and final stages of the instrument development process. Also, several EFL teachers and students, familiar with Edmodo, provided suggestions and remarks which aided in considering, improving and restating some items. Their comments improved the instrument's face validity.

\subsection{Method of Analysis}

Data collected from the questionnaires were statistically analyzed using the statistical analysis program SPSS. Some descriptive statistics such as means, percentage and frequency were used. Moreover, some inferential statistical procedures were used such as the t-test.

\section{Results and Discussion}

\subsection{Edmodo and EFL Students'Motivation}

Results showed that all 21 statements in the questionnaire had means higher than 2.5, thus this indicated the presence of motivation among students. The overall mean that refers to the presence of motivation among EFL students when using Edmodo must be higher than 52.5 based on the following formula: 21 items $\times 2.5$ average mean $=52.5$. The results indicated that the overall mean of students' responses to the statements is 67.27 , which is higher than 52.5, hence EFL students were being motivated via Edmodo.

In order to know if there is a statistically significant difference between the general mean of statements 52.5 and the mean of students' responses 67.27, one sample (t) test was run to compare between the two means. The result is in the following table:

Table 1. One Sample (t) Test - Students' Motivation

\begin{tabular}{ccccccc}
\hline & N & Mean & Mean Difference & df & t & Sig. (2-tailed) \\
\hline Sample & 255 & 67.27 & 14.77 & 254 & 26.80 & 0.000 \\
\hline
\end{tabular}

Table (1) above indicates that there is a statistically significant difference between the two 
means $(\alpha \leq 0.05)$. The mean of students' responses to the items related to motivation was statistically significantly higher than the general mean of statements, $\mathrm{t}(254)=26.80, \mathrm{p}=$ 0.000. Therefore, to answer the research question, Edmodo has a positive impact on students' motivation in their language learning process.

Moreover, results showed that the responses to the items 8,12,13,14, and 16 got the highest averages. These items examined specifically the effect of Edmodo's ease of use, flexibility in time and place of learning, and recognition features on students' motivation. The majority of students apparently found these factors the most influential in their adoption of Edmodo, and in Edmodo's capability to raise their motivation in learning. This finding indicated that students prefer their education to be as developing, yet flexible and convenient as their life styles. They also like their educational requirements to meet their technical experiences and expectations.

On the other hand, the lowest average was recorded in item 5. This decrease can be attributed to students' unfamiliarity with the various communities on Edmodo. If Edmodo were adopted by many courses, students would devote much time to navigate the website and learn about its other features.

\subsection{Edmodo and Teacher-Student's Communication}

Results showed that all 19 statements in the questionnaire had means higher than 2.5, thus it suggested the presence of teacher-student's communication. According to the following formula: 19 items $\times 2.5$ average mean $=47.5$, the overall mean that refers to the presence of teacher-student's communication through Edmodo must be higher than 47.5. The results indicated that the overall mean of students' responses to the statements is higher than 47.5. It is 61.62, which meant that Edmodo promoted effective teacher-student's communication.

One sample (t) test was run to determine if the difference between the general mean of statements 47.5 and the mean of students' responses 61.62 is statistically significant. The following table illustrates the result of the $(\mathrm{t})$ test:

Table 2. One Sample (t) Test - Teacher-Student's Communication

\begin{tabular}{ccccccc}
\hline & N & Mean & Mean Difference & df & t & Sig. (2-tailed) \\
\hline Sample & 255 & 61.62 & 14.12 & 254 & 24.78 & 0.000 \\
\hline
\end{tabular}

Table (2) above indicates that there is a statistically significant difference between the two means $(\alpha \leq 0.05)$. The mean of students' responses to the items related to teacher-student's communication through Edmodo was statistically significantly higher than the general mean of statements, $\mathrm{t}(254)=24.78, \mathrm{p}=0.000$. As an answer to the research question, Edmodo influences positively the nature of communication between teachers and students.

It was obviously clear that most students appreciated the different aspects of communication on Edmodo in slightly varying averages. Items 24,33 , and 35, which were related to verbal 
and non-verbal communication and confidentiality, had the highest averages among the others. This increase can be credited to the fact that these features are considered most students' required characteristics in any communication tool adopted by teachers. Students like to receive quick and meaningful feedback on their performance. They also like to be informed about their progress and course requirements during the semester, while insuring their privacy in communication.

\subsection{Edmodo Features Results}

In the questionnaire, students were asked what features do they like the most on Edmodo, as well as what features do they dislike the most on Edmodo. It is worth mentioning that students were allowed to choose more than one feature. The following tables (3) and (4) show the results of students' responses to the Edmodo features.

Table 3. Frequency and Percentage of the Features That Students Like the Most

\begin{tabular}{ccc}
\hline Edmodo Features & Frequency & Percentage \\
\hline Small Groups & 64 & 5.2 \\
Notifications & 94 & 7.6 \\
Posts and Replies & 99 & 8.0 \\
Polls & 95 & 7.7 \\
Alerts & $\mathbf{1 2 2}$ & $\mathbf{9 . 9}$ \\
Reactions & 104 & 8.4 \\
Quizzes & $\mathbf{1 7 3}$ & $\mathbf{1 4 . 0}$ \\
Progress & 97 & 7.8 \\
Assignments & $\mathbf{1 4 6}$ & $\mathbf{1 1 . 8}$ \\
Badges & 75 & 6.1 \\
Backpack & 93 & 7.5 \\
Edmodo Planner & 64 & 5.2 \\
Other & 11 & 0.9 \\
Total & $\mathbf{1 2 3 7}$ & $\mathbf{1 0 0}$ \\
\hline
\end{tabular}

As table (3) shows, the total number of students' likes (1237), which compared to the students' actual number (255), indicated a great enthusiasm and preference in Edmodo use in their language learning process. Students apparently preferred "Alerts", "Quizzes" and "Assignments" (the bolded cells in Table 3) more than any other Edmodo feature for they got the highest percentages of likes: $14.0 \%$ for "Quizzes", $11.8 \%$ for "Assignments", and 9.9\% for "Alerts". It was noticed that the most liked features were the ones especially used for educational purposes and probably were not available on any other social network. This result showed that engaging learning activities, which can be done through these features, played a major role in students' preference to use Edmodo. For even the typically undesirable tools of assessment became their favorite via these features. Teachers can attach files, pictures, videos 
and links within their assignments and quizzes, and their students will be able to do them online in the comfort of their homes.

Table 4. Frequency and Percentage of the Features that Students Dislike the Most

\begin{tabular}{ccc}
\hline Edmodo Features & Frequency & Percentage \\
\hline Small Groups & 16 & 7.0 \\
Notifications & 18 & 7.9 \\
Posts and Replies & 36 & $\mathbf{1 5 . 7}$ \\
Polls & 11 & 4.8 \\
Alerts & 16 & 7.0 \\
Reactions & 15 & 6.6 \\
Quizzes & 19 & 8.3 \\
Progress & 8 & 3.5 \\
Assignments & 31 & $\mathbf{1 3 . 5}$ \\
Badges & 3 & 1.3 \\
Backpack & 12 & 5.2 \\
Edmodo Planner & 21 & 9.2 \\
Other & 23 & 10.0 \\
Total & $\mathbf{2 2 9}$ & $\mathbf{1 0 0}$ \\
\hline
\end{tabular}

Table (4) shows that the total number of students' dislikes (229) was significantly low, compared to the total number of students (255) and the total number of students' likes (1375). This result proved that the majority of students agreed to the effectiveness of most of its features. "Posts and Replies" and "Assignments" got the highest dislikes with a percentage of $15.7 \%$ to $13.5 \%$. Students' opinions on such features can be affected by certain variables like student-characteristics or teacher-characteristics. Some students do not prefer to use "Posts and Replies" because they are not available online during the day, and that makes it hard for them to follow teachers' posts and discussion threads. Furthermore, some teachers who use such features excessively or who are not skillful enough to create engaging assignments or discussions would result in students' dislike of them. Thus, teachers should acknowledge their significant role in employing such features to the maximum potential because these features are only motivating when teachers use them effectively.

\subsection{Study Results and Previous Studies}

The results of the study add to the current body of knowledge by introducing quantitative evidence on the effectiveness of integrating educational networking sites, in this case Edmodo, in EFL classrooms. The study concluded that incorporating Edmodo encourages students' motivation towards language learning, as it possesses certain features such as ease of use, flexibility in time and place of learning, and recognition features. Several previous studies have proposed such possibility of increased students' engagement and enjoyment in learning through Edmodo (Sanders, 2012; Wolfer, 2012; Fardoun et al., 2012). For instance, 
Sanders (2012) noted that the use of Edmodo could provide learning opportunities that engages, motivates, and inspires students to learn on their own. Also, Fardoun et al. (2012) reported that many students have participated actively and constantly in Edmodo, and they find it interesting to use in education. Moreover, the study concluded by highlighting Edmodo's impact in promoting teacher-student communication for it fosters certain characteristics, rare in other social networks, such as verbal and non-verbal communication and confidentiality. Thongmak (2013), Baruah (2012), Boyd \& Ellison (2007) and Zaidieh (2012) all agreed that social networks are effective communication tools that can enhance students' collaboration and feedback between teachers and students. For instance, Khedo et al. (2012) investigated the use of online social networking as a tool to improve learning in the Mauritian education system. As a result, $80.5 \%$ of learners revealed that they used online social networking as communication tools through chatting and messaging. Furthermore, Thongmak (2013) conducted a study on students' perception of Edmodo, in which they argued that Edmodo allows teachers to communicate directly with learners when giving assignments or instructions. Learners also indicated that instructors easily check assignments with more privacy in comparison to other social networks. Thus, most previous studies are in alignment with the results of this study and support its conclusions. However, compared to the previous studies, the results of this study focuses on these two aspects of language learning, giving more insight into Edmodo as an educational social website and providing Saudi university students with a chance to voice their opinions on its use.

\section{Conclusion, Recommendations and Future Research}

\subsection{Summary of Major Findings}

The research examines two questions associated with how incorporating Edmodo affects EFL students' learning at Princess Nourah bint Abdulrahman University. The first question dealt with its impact on EFL students' motivation and the second one was about its impact on the nature of communication between teachers and students. After investigating these questions, the following conclusions were made: integrating Edmodo promotes EFL students' motivation and teacher-student's communication. EFL students show a notable willingness and preference in using Edmodo in language learning, and they like most features available there such as "Quizzes". However, some students dislike few features such as "Posts and Replies". Reasons behind students' choices of most liked or disliked features on Edmodo are not stated by the students, but nonetheless explained earlier by the researcher based on experience.

\subsection{Implications of the Study}

On the basis of data interpretation and conclusions of the study, the following recommendations were made:

1. Since Edmodo proved its effectiveness on EFL university students of the current research, it is suggested that teachers of all disciplines utilize Edmodo or any similar networking site in their classrooms. Employing Edmodo seems to create an active educational 
environment where everything students need is at hand.

2. Teachers who use Edmodo are recommended to conduct monthly meetings dedicated to sharing experiences and overcoming obstacles.

3. Edmodo is only motivating when teachers use it effectively. Thus, teachers should utilize many of its features and design creative learning activities to provide their students with a full online educational experience.

4. Edmodo aids teachers allocate assignments and make and mark quizzes. Such easiness might lead some teachers to assign more than what their students are capable of doing especially if with given deadlines. Hence, teachers should take their students' abilities and skills into consideration because the learning process via Edmodo is intended to be an enjoyable non-threatening experience.

5. Since "Posts and Replies" was not students' favorite feature, teachers are suggested to schedule the time and vote the topic of discussion in advance. This procedure ensures students' availability and interest for the discussion.

6. It is recommended that all Saudi universities adopt Edmodo or any similar networking site to increase the number of its users, which in turn forms a large Saudi community to exchange ideas and opinions on education.

7. Since Edmodo proved effective on the investigated variables, it can then be used in distance learning programs for it might help bridge the gap between students and teachers and provide some flexibility in time and place of learning.

\subsection{Suggestions for Further Research}

The findings are in alignment with the recent research on the significance of technology integration in education and the important role of social networks in language learning, however:

1. The present study was conducted on Saudi EFL students at Princess Nourah bint Abdulrahman University with only 255 students. Other studies can be done with larger samples in different universities.

2. The current research was restricted to female participants, therefore, it is highly recommended to explore using Edmodo on male students at other Saudi universities as gender plays a paramount role on language learning (Aslan, 2009).

3. The subjects of this study were university students, so other studies could deal with students at schools whose age, English level, and computer skills might affect the investigated variables.

4. Other studies could investigate the effect of Edmodo on different aspects of learning such as student participation and creative writing...etc. These studies might provide an insight regarding its status as an effective educational social networking site.

5. Other studies could also examine the effectiveness of Edmodo when used in distance or 
online learning programs. Such programs require an effective tool to build a community for both teachers and students.

\section{References}

Aslan, O. (2009). The Role of Gender and Language Learning Strategies in Learning English (Master's thesis). Retrieved from http://etd.lib.metu.edu.tr/upload/12611098/index.pdf

Barbour, M., \& Plough, C. (2009). Social Networking in Cyberschooling: Helping to Make Online Learning Less Isolating. TechTrends, 53(4), 56-60.

Baruah, T. (2012). Effectiveness of Social Media as a Tool of Communication and its Potential for Technology Enabled Connections: A Micro-level Study. International Journal of Scientific and Research Publications, 2(5), 126-135.

Beebe, S. A., \& Mottet, T. P. (2009). Students and Teachers. 21st Century Communication: A Reference Handbook (pp. 349-57). Thousand Oaks: Sage Publications. http://dx.doi.org/10.4135/9781412964005

Boyd, D., \& Ellison, N. (2007). Social Network Sites: Definition, History, and Scholarship. Journal of Computer-Mediated Communication, 13(1), 210-230. http://dx.doi.org/10.1111/j.1083-6101.2007.00393.x

Brady, P., Holcomb, B., \& Smith, B. (2010). The Use of Alternative Social Networking Sites in Higher Educational Settings: A Case Study of the E-Learning Benefits of Ning in Education. Journal of Interactive Online Learning, 9(2), 151-170.

Conole, G. (2010). Facilitating new forms of discourse for learning and teaching: Harnessing the power of Web 2.0 practices. Open Learning, 25(2), 141-151. https://doi.org/10.1080/02680511003787438

Cronbach, L. J. (1951). Coefficient Alpha and the Internal Structure of Tests. Psychometrika, 16, 297-334.

del Val, J. L., Campos, A., \& Garaizar, P. (2010). LMS and Web 2.0 Tools for E-Learning: University of Deusto's Experience Taking Advantage of Both. Proceedings of IEEE EDUCON Education Engineering 2010, 1751-1757, Madrid, Spain. Retrieved from http://paginaspersonales.deusto.es/garaizar/papers/EDUCON2010-JLV-PG-AC.pdf

Dörnyei, Z. (1998). Motivation in second and foreign language learning. Language Teaching, 31(03), 117-135. http://dx.doi.org/10.1017/S026144480001315X

Fardoun, H., Alghazzawi, D., Romero, S., Penichet, V., \& Gallud, J. (2012). Online Social Networks Impact in Secondary Education. International Workshop on Evidence-Based Technology Enhanced Learning Advances in Intelligent and Soft Computing, 152, 37-45. http://dx.doi.org/10.1007/978-3-642-28801-2_5

Gamoran, A. (2011). Benefits and Drawbacks of Social Media in Education. WCER Research, 
22(4), 1-7.

Greenhow, C., \& Robelia, B. (2009). Old communication, new literacies: Social network sites as social learning resources. Journal of Computer-mediated Communication, 14(4), 1130-1161. http://dx.doi.org/10.1111/j.1083-6101.2009.01484.x

Hershkovitz, A., \& Baruch, A. (2010). The Use of Social Networks by Higher-Education Institutes in Israel. Proceedings of the Chais conference on instructional technologies research 2011: Learning in the technological era, Israel. Retrieved from http://www.openu.ac.il/research_center/chais2011/download/Forkosh_Hershkovitz.pdf

Hewes, B. (2010). Edmodo keeps getting better! [Blog post]. Retrieved from http://biancahewes.wordpress.com/2010/10/24/edmodo-keeps-getting-better/

Hurt, H. T., Scott, M. D., \& McCroskey, J. C. (1978). Communication in the classroom. Reading, MA: AddisonWesley

Khedo, K., Mocktoolah, M., \& Suntoo, R. (2012). Online Social Networking as a Tool to Enhance Learning in the Mauritian Education System. Journal of Emerging Trends in Computing and Information Sciences, 3(6), 907-912.

Kirschner, A., \& Karpinski, C. (2010). Facebook and academic performance. Computers in Human Behaviour, 26(6), 1237-1245. http://dx.doi.org/10.1016/j.chb.2010.03.024

Kongchan, C. (2012). How a Non-Digital-Native Teacher Makes Use of Edmodo. Proceedings of 2012 ICT for Language Learning Conference, $5^{\text {th }}$ edition, Florence, Italy. Retrieved from http://conference.pixel-online.net/ICT4LL2012/common/download/Paper_pdf/90-IBT18 -FP-Kongchan-ICT2012.pdf

Kongchan, C. (2012). How a Non-Digital-Native Teacher Makes Use of Edmodo. Proceedings of 2012 ICT for Language Learning Conference, Florence, (Italy), 15 - 16 November 2012.

Picardo, J. (2010). Microblogging: making the case for social networking in education [Blog post]. $\quad$ Retrieved from http://www.boxoftricks.net/2010/02/microblogging-making-the-case-for-social-networki ng-in-education/

Sanders, K. S. (2012). An Examination of the Academic Nnetworking Site Edmodo on Student Engagement and Responsible Learning (Doctoral dissertation). Retrieved from http://scholarcommons.sc.edu/etd/873

Selwyn, N. (2009). Faceworking: Exploring Students' Education-Related Use of Facebook. $\begin{array}{llll}\text { Learning, } \quad \text { Media } \quad \text { and } & \text { 157-174. }\end{array}$ http://dx.doi.org/10.1080/17439880902923622

Simon, M.K., \& Goes, J. (2013). Scope, limitations, and delimitations. (Excerpts from Dissertation and Scholarly Research: Recipes for Success). Retrieved from 
http://dissertationrecipes.com/wp-content/uploads/2011/04/limitationscopedelimitation1. pdf

Thongmak, M. (2013). Social Network System in Classroom: Antecedents of Edmodo at Adoption. Journal of e-Learning and Higher Education, 13(49), 66-72. http://dx.doi.org/10.5171/2013.657749

Tiryakioglu, F., \& Erzurum, F. (2011). Use of Social Networks as an Education Tool. Contemporary Educational Technology, 2(2), 135-150.

Weber, S. (2012). Considerations for Social Network Site (SNS) Use in Education. International Journal of Digital Information and Wireless Communications, 2(4), 37-52. ISSN: 2225-658X

Winant, C. (2014). Earth science resources [Online forum post]. Retrieved from https://www.edmodo.com/post/356393709

Wolfer, C. (2012). Effects on Student Engagement and Comprehension when Using Microblogging with Fourth Grade Reading Groups. Retrieved from http://ar515.wikispaces.com/file/view/CrystalW_ActionResearch.pdf

Young, A. L., \& Quan-Haase, A. (2009). Information Revelation and Internet Privacy Concerns on Social Network Sites: A Case Study of Facebook. Proceedings of the Fourth International Conference on Communities and Technologies, University Park, PA, USA, 265-274. ACM 978-1-60558-601-4/09/06

Zaidieh, A.J. (2012). The Use of Social Networking in Education: Challenges and Opportunities. World of Computer Science and Information Technology Journal, 2(1), 18-21.

\section{Copyright Disclaimer}

Copyright for this article is retained by the author(s), with first publication rights granted to the journal.

This is an open-access article distributed under the terms and conditions of the Creative Commons Attribution license (http://creativecommons.org/licenses/by/3.0/). 